\title{
Raw Chinese Yam (Dioscorea opposita) Promotes Cecal Fermentation and Reduces Plasma Non-HDL Cholesterol Concentration in Rats
}

\author{
Naomichi Nishimura ${ }^{1}$, Hiroki TANABE $^{1}$, Tatsuro YAmAmoto $^{1}$ and Michihiro Fukushima ${ }^{2}$ \\ ${ }^{1}$ Department of Nutritional Sciences, Faculty of Health and Welfare Science, Nayoro City University, \\ Nayoro, Hokkaido 096-8641, Japan \\ ${ }^{2}$ Department of Animal Science, Obihiro University of Agriculture and Veterinary Medicine, \\ Obihiro, Hokkaido 080-8555, Japan \\ (Received January 21, 2011)
}

\begin{abstract}
Summary We examined the effects of raw Chinese yam (Dioscorea opposita), containing resistant starch (RS), on lipid metabolism and cecal fermentation in rats. Raw yam (RY) and boiled yam (BY) contained 33.9\% and 6.9\% RS, respectively. Male Sprague-Dawley rats were fed a cholesterol-free, control (C) diet supplemented with or without 15 and $30 \mathrm{~g}$ of RY or BY/100 g for $3 \mathrm{wk}$. Plasma total cholesterol concentrations in the tail vein of rats fed the $30 \% \mathrm{RY}$ diet were significantly lower than in the $\mathrm{C}$ group throughout the feeding period. Compared with the C group, non-HDL concentrations in arterial plasma in the $30 \% \mathrm{RY}$ group was significantly reduced. Liver cholesterol concentration in rats fed the $30 \% \mathrm{RY}$ diet was significantly higher compared with those fed the $\mathrm{C}$ diet. Hepatic cholesterol $7 \alpha$-hydroxylase mRNA and fecal bile acid excretion were significantly higher in the BY, but not the RY group, compared with the $\mathrm{C}$ group. Fecal cholesterol excretion in the $30 \% \mathrm{RY}$ group was greater compared with the $\mathrm{C}$ group. Hepatic microsomal triacylglycerol transfer protein mRNA was significantly lower in the $30 \% \mathrm{RY}$ group compared with the C group. Cecal pools of acetate, propionate and butyrate were $113-257 \%, 181-476 \%$ and $410-789 \%$ greater in the $\mathrm{RY}$ group compared with the $\mathrm{C}$ group. These results suggest raw yam is effective as a source of RS and facilitates production of short chain fatty acid (SCFA), especially butyrate, in the rat cecum. In addition, RY has a plasma-cholesterol lowering effect, possibly due to the inhibited release of VLDL.
\end{abstract}

Key Words Chinese yam, resistant starch, cholesterol, fermentation, rats

Yams, the edible tubers of various species of the genus Dioscorea, are important in the diets of many countries in Asia and Africa and are also widely used in most parts of the world because of the carbohydrate they provide. Yam is composed mainly of starch with small amounts of proteins, lipids and most vitamins; it is also very rich in minerals. Chinese yam, Dioscorea opposita, has been used as a herbal medicine as well as a food in Japan (1), Korea and China, and it is assumed Chinese yam has some physiological and pharmacological actions $(2,3)$. However, few studies have examined the properties of Chinese yam. Chinese yam is high in starch and, in Japan, is unique in that it is generally consumed raw. Raw starches are digested slowly in the alimentary tract, resulting in the delivery of starch to the large intestine. These starches are referred to as resistant starch (RS) and act as dietary fibre-like compounds. RS has a hypolipidemic effect and a promoting effect on colonic microbiota and fermentation.

RS is classified into 4 types: RS1 (physically inaccessible or digestion-resistant starch), RS2 (raw granular starch), RS3 (retrograded starch) and RS4 (starches that have been chemically modified to resist digestion).

E-mail: nishimura@nayoro.ac.jp
Many studies have reported on the physiological effects of RS2 and RS3, but not RS1 or RS4. The effects of RS2 and RS3 are similar. Although raw high amylose cornstarch, banana starch and potato starch have been used as RS2 sources in most studies reporting physiological effects, other sources of RS2 have not been examined yet. In addition, it is rare to consume large amounts of RS2 in a typical meal, because most foodstuffs containing large amounts of starch are usually cooked. However, in Japan, Chinese yam is one of the few sources of RS2 which is available in an ordinary meal in Japan.

RS, including RS2 and RS3, reduces plasma cholesterol and triacylglycerol (TAG) concentrations in rats $(4,5)$ and humans $(6)$ and promotes the production of short chain fatty acid (SCFA), especially butyrate, in rodents $(7,8)$ and humans (9). SCFA production in the large intestine contributes to inhibited hepatic cholesterol synthesis (10) and could suppress the proliferation of colon cancer cells (11). These effects are assumed to prevent the development of coronary heart disease and colon cancer. Sufficient amounts of RS are not easily consumed in a habitual diet; therefore, raw Chinese yam could be a valuable source of RS.

We aimed to examine the physiological effects of raw Chinese yam on plasma lipid concentrations and cecal 
Table 1. Composition of raw and boiled Chinese yam powder. $^{1}$

\begin{tabular}{lrr}
\hline & RY & BY \\
\hline Composition $(\%, w / w)$ & & \\
Carbohydrate & 83.4 & 86.7 \\
Resistant starch & 33.9 & 6.9 \\
Protein & 10.1 & 8.1 \\
Lipid & 0.6 & 0.4 \\
Ash & 4.7 & 2.9 \\
Dietary fiber & 5.1 & 8.9 \\
Soluble & 1.9 & 1.8 \\
Insoluble & 3.2 & 7.1 \\
Moisture & 1.2 & 1.9 \\
\hline
\end{tabular}

${ }^{1} \mathrm{RY}$, raw yam; BY, boiled yam.

fermentation. In the present study, we examined the effects of raw Chinese yam on plasma lipid concentration and cecal SCFA concentration compared to boiled Chinese yam in rats.

\section{MATERIALS AND METHODS}

Preparation of yam. Yam was supplied by JA Obihiro Kawanishi. The yam was peeled, sliced and immediately freeze-dried, or boiled for $1 \mathrm{~min}$ and freeze dried. Lyophilized samples were powdered as raw yam powder (RY) and boiled yam powder (BY). Carbohydrate, protein, lipid, ash, moisture and RS contents in RY and BY are shown in Table 1.

Animals and diets. The study was approved by Nayoro City University Animal Use Committee, and the animals were maintained in accordance with guidelines for the care and use of laboratory animals, Nayoro City University.

Male Sprague-Dawley rats weighing 80-90 g (4 wk old) were obtained from Japan SLC, Inc. (Shizuoka, Japan). They were housed in individual cages with screen bottoms of stainless steel in a room maintained at $23 \pm 1{ }^{\circ} \mathrm{C}$ with lighting from 0700 to $1900 \mathrm{~h}$. Rats were acclimated by feeding a $20 \%$ casein control diet, free of cholesterol for $10 \mathrm{~d}$, before feeding test diets. The basic composition of the control diet was $(\mathrm{g} / \mathrm{kg})$ : casein, 200; $\alpha$-cornstarch, 529.5; sucrose, 100; soybean oil, 70; AIN-93G mineral mix (12), 35; AIN-93 vitamin mix (12), 10; L-cystine, 3; choline bitartate, 2.5; and cellulose, 50 .

After the acclimation period, rats were divided into 5 groups of six, based on body weight and plasma cholesterol concentration and were administered test diets for $21 \mathrm{~d}$. Each group was fed the control diet supplemented with or without 150 or $300 \mathrm{~g}$ of RY or BY per kg. RY and BY were substituted for $\alpha$-cornstarch. Body weight and food intake were recorded daily, and feces were collected during the last $3 \mathrm{~d}$, lyophilized and weighed. We determined the total plasma cholesterol concentration in blood samples collected from the tail vein on day 0,3 , 7, 10, 14 and 21. After $21 \mathrm{~d}$, rats were deprived of food for $2 \mathrm{~h}$ before sacrifice, to avoid the change in cholesterol metabolism due to prolonged fasting. The rats were anesthetized with Nembutal (sodium pentobarbital, $50 \mathrm{mg} / \mathrm{kg}$ body wt.) and blood was removed by abdominal aorta puncture into a centrifuge tube via a catheter. Plasma was separated by centrifugation at $1,200 \times g$ for $20 \mathrm{~min}, 4^{\circ} \mathrm{C}$. The liver was removed, weighed, immediately frozen in liquid nitrogen and stored at $-80^{\circ} \mathrm{C}$ until being analyzed for cholesterol and mRNA of cholesterol $7 \alpha$-hydroxylase (CYP7A1), hydroxymethylglutaryl-CoA reductase (HMG-CoA-r), LDL receptor (LDL-R), Apo B, microsomal TAG transfer protein (MTP) and glyceraldehyde-3-phosphate dehydrogenase (GAPDH) genes. The epididymal fat pad and testes were removed, blotted, and weighed. The cecum was removed and weighed, and the $\mathrm{pH}$ of the cecal contents was measured with a $\mathrm{pH}$ meter (model F-52 equipped with a $\mathrm{pH}$ microsensor (9669-10D), Horiba, Kyoto, Japan). The cecal content was collected and stored at $-40^{\circ} \mathrm{C}$ in air-tight tubes until being analyzed for SCFA. The cecal wall was blotted and weighed after rinsing in an ice-cold saline solution.

Biochemical analyses. The lipoprotein fractions were analyzed enzymatically to determine the concentrations of total cholesterol, lipoprotein cholesterol, esterified and non-esterified cholesterol, TAG, phospholipids and non-esterified fatty acids using an autoanalyzer (model AU-5400, Olympus, Tokyo, Japan).

To measure total liver cholesterol and TAG, liver lipids were extracted with chloroform/methanol $(2: 1, \mathrm{v} / \mathrm{v})$ according to the method of Folch et al. (13). Aliquots of this extract were dried under a nitrogen stream, and the residue obtained was mixed with isopropanol containing 10\% (v/v) Triton X-100 (Wako Pure Chemical Industries, Ltd., Tokyo, Japan) or isopropanol. These mixtures were used to determine the cholesterol and TAG concentrations using a commercial kit (Cholesterol E-test, Wako) and the method of Fletcher (14), respectively. In a preliminary study, $20 \mu \mathrm{L}$ of isopropyl alcohol containing $100 \mathrm{~g}$ Triton $\mathrm{X}-100 / \mathrm{L}$ did not affect the enzymatic reactions in a cholesterol assay (data not shown).

Fecal lipids were extracted from the lyophilized feces using 40 vol of $0.5 \mathrm{M}$ ethanolic $\mathrm{KOH}$ at $80^{\circ} \mathrm{C}$ for $2 \mathrm{~h}$ (15). Neutral sterol was extracted from prepared fecal lipid samples with $n$-hexane. Cholesterol and coprostanol were measured after trimethylsilyl derivatization using a gas chromatography system (GC-17A, Shimadzu, Kyoto, Japan) equipped with CP-Sil $8 \mathrm{CB}$ $(0.25 \mathrm{~mm} \times 25 \mathrm{~m}, \quad 0.12 \mu \mathrm{m} ; \quad$ Agilent Technologies, Tokyo, Japan) (15). Total bile acid was enzymatically analyzed using the $3 \alpha$-hydroxysteroid dehydrogenase assay (EC 1.1.1.50) of Sheltawy and Losowsky (16) and lithocholic acid as a standard.

After homogenization of the cecal contents, cecal organic acids (acetate, propionate, $n$-butyrate and succinate) were measured (17) using a HPLC system (LC10A, Shimadzu) equipped with a Shim-pack SCR-102H column $(8 \mathrm{~mm} \times 30 \mathrm{~cm}$, Shimadzu $)$ and an electroconductivity detector (CDD-6A, Shimadzu). Briefly, 300 $\mathrm{mg}$ of cecal contents were homogenized in $2 \mathrm{~mL}$ of $10 \mathrm{~mm} \mathrm{NaOH}$ and then centrifuged at $10,000 \times g$ for 
Table 2. Primer sequences used in mRNA quantification by real-time RT-PCR. ${ }^{1}$

\begin{tabular}{lll}
\hline \multicolumn{1}{c}{ Gene } & \multicolumn{1}{c}{ Forward $\left(5^{\prime} \rightarrow 3^{\prime}\right)$} & \multicolumn{1}{c}{ Reverse $\left(5^{\prime} \rightarrow 3^{\prime}\right)$} \\
\hline CYP7A1 & CAACTGAATGACCTGCCGGTACTA & GGAACCGTCCTCAAGATGGAGA \\
HMG-CoA-r & ACGTTCACCCTTGACGCTCTG & AGTTGGCAAGCACGGACATACA \\
LDL-R & ACCCAGAGCCATCGTAGTGGAC & TGGAGTTTGGAATCAACCCAATAGA \\
Apo B & GGGTGAGGCTGTACGTACTGGAA & CCTTTGGTAATGGCAGCTTTGAA \\
MTP & CGACCCTGTCAGTGTGGTGAA & TGAACCAGAAATGTCAATGGCTAGA \\
GAPDH & GACAACTTTGGCATCGTGGA & ATGCAGGGATGATGTTCTGG \\
\hline
\end{tabular}

${ }^{1}$ CYP7A1, cholesterol $7 \alpha$-hydroxylase; HMG-CoA-r, hydroxymethylglutaryl-CoA reductase; LDL-R, LDL receptor; Apo B, apolipoprotein B; MTP, microsomal TAG transfer protein; GAPDH, glyceraldehyde-3-phosphate dehydrogenase.

$15 \mathrm{~min}$. The supernatant obtained was applied to HPLC analysis.

Real-time PCR analysis of CYP7A1, HMG-CoA-r, LDL$R$, Apo B and MTP. Total RNA was extracted from the liver using an RNeasy Mini Kit (QIAGEN, Tokyo, Japan) and reverse-transcribed using a Reverse Transcriptase kit (PrimeScript RT reagent Kit, Takara Bio Inc., Otsu, Japan). The primers for rat CYP7A1, HMG-CoA-r, LDLR, Apo B, MTP and GAPDH were designed by TaKaRa Perfect Real Time Support System (Takara); the sequences are listed in Table 2. GAPDH was used as an endogenous control. The primers were purchased from Takara Bio Inc. Real-time PCR was carried out in triplicate for each sample on a Stratagene Mx3000P (Stratagene) using a SYBR Premix Ex Taq kit (Takara). For each sample, results were normalized to GAPDH.

Statistical analysis. Experimental data were statistically analyzed by one-way ANOVA, followed by TukeyKramer's post-hoc test. Pearson's correlation coefficient was used to evaluate correlations between dependent variables. Differences with $p$-values of 0.05 or less were considered significant. Data are presented as means \pm SE unless otherwise indicated. All statistical analyses were performed using SAS JMP software (version 8.0.1; Tokyo, Japan).

\section{RESULTS}

Body weight gain and food intake did not differ between groups (control, $157 \pm 4$ and $429 \pm 16 \mathrm{~g} / 21 \mathrm{~d}$; $15 \mathrm{RY}, 134 \pm 10$ and $402 \pm 16 \mathrm{~g} / 21 \mathrm{~d}$; 30RY, $132 \pm 8$ and $394 \pm 18 \mathrm{~g} / 21 \mathrm{~d} ; 15 \mathrm{BY}, 147 \pm 6$ and $415 \pm 15 \mathrm{~g} /$ $21 \mathrm{~d}$; 30BY, $154 \pm 10$ and $419 \pm 22 \mathrm{~g} / 21 \mathrm{~d}$ ). In addition, energy intake did not differ between groups (control, $6.95 \pm 0.26 \mathrm{MJ} / 21 \mathrm{~d} ; 15 \mathrm{RY}, 6.48 \pm 0.28 \mathrm{MJ} / 21 \mathrm{~d}$; 30RY, $6.27 \pm 0.28 \mathrm{MJ} / 21 \mathrm{~d}$; $15 \mathrm{BY}, 6.67 \pm 0.23 \mathrm{MJ} / 21 \mathrm{~d}$; 30BY, $6.69 \pm 0.35 \mathrm{MJ} / 21 \mathrm{~d}$ ). Figure 1 shows the time course of changes in plasma cholesterol concentration in rats fed diets containing raw and boiled yam. After $3 \mathrm{~d}$ feeding, plasma cholesterol concentrations were significantly lower $(p<0.05)$ in rats fed the $30 \% \mathrm{RY}$ diet compared with those fed the control diet; the lower values were maintained over $21 \mathrm{~d}$. However, significant reductions in plasma cholesterol were not observed in rats fed the other diets (15\% RY, 15\% BY and 30\% BY).

At the end of the experimental period, there was a tendency for total cholesterol concentrations in arterial

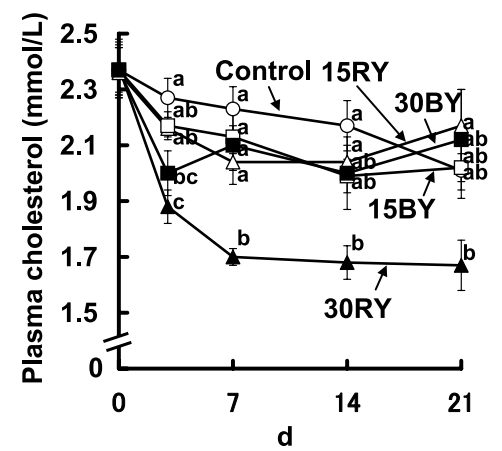

Fig. 1. Change in plasma cholesterol concentration in rats fed the raw yam (RY) and boiled yam (BY) diets. Each point is the mean of six rats; vertical bar represent SE. Values at each time point not sharing a common letter are significantly different $(p<0.05)$. Statistical comparisons were made with Tukey-Kramer's post-hoc test. Control $(O$, rats fed the control diet); $15 R Y(\triangle$, rats fed the 15\% RY diet); 30RY ( $\mathbf{\Lambda}$, rats fed the control diet); $15 \mathrm{BY}(\square$, rats fed the control diet); 30BY (ם, rats fed the control diet).

plasma to be lower in rats fed the $30 \% \mathrm{RY}$ diet compared with those fed the control diet, but the differences were not statistically significant $(p=0.0728$; Table 3$)$. Plasma non-HDL cholesterol concentrations were significantly lower in rats fed the $30 \% \mathrm{RY}$ diet compared with those fed the control diet. Compared with rats fed the control diets, plasma TAG concentrations in rats fed all diets, excluding the $15 \% \mathrm{BY}$ diet, were significantly lower, and the dose-dependent supplementation of RY enhanced this reduction.

Epididymal fat pad weights were significantly lower in rats fed the $30 \% \mathrm{RY}$ diet compared with those fed the control diet (Table 4). There were no significant differences in liver weights between the groups. Liver cholesterol concentrations were higher in rats fed the $30 \% \mathrm{RY}$ diet compared with those fed the control diet (Table 4). Liver TAG levels did not differ among the groups.

Table 5 indicates fecal weight and bile acid excretion in rats fed RY and BY. The excretions of feces and cholesterol were significantly higher in rats fed the 30\% RY diet compared with those fed the control diet. Only rats fed BY, but not RY, excreted significantly less coprostanol and more total fecal bile acids compared with those fed the control diet. 
Table 3. Effect of raw and boiled yam on lipid concentration in arterial plasma. ${ }^{1,2}$

\begin{tabular}{lccccc}
\hline & Control & $15 \mathrm{RY}^{3}$ & $30 \mathrm{RY}^{3}$ & $15 \mathrm{BY}^{4}$ & $30 \mathrm{BY}$ \\
\hline Cholesterol & & & & & \\
Total (mmol/L) & $1.96 \pm 0.10$ & $1.86 \pm 0.11$ & $1.55 \pm 0.09$ & $1.87 \pm 0.05$ & $1.90 \pm 0.14$ \\
HDL (mmol/L) & $0.754 \pm 0.024$ & $0.733 \pm 0.024$ & $0.694 \pm 0.029$ & $0.772 \pm 0.025$ & $0.707 \pm 0.032$ \\
Non-HDL (mmol/L) & $1.20 \pm 0.08^{\mathrm{a}}$ & $1.13 \pm 0.10^{\mathrm{ab}}$ & $0.854 \pm 0.067^{\mathrm{b}}$ & $1.10 \pm 0.04^{\mathrm{ab}}$ & $1.19 \pm 0.12^{\mathrm{ab}}$ \\
Esterified (mmol/L) & $1.77 \pm 0.09$ & $1.73 \pm 0.10$ & $1.47 \pm 0.08$ & $1.62 \pm 0.16$ & $1.78 \pm 0.13$ \\
Free (mmol/L) & $0.185 \pm 0.033$ & $0.133 \pm 0.012$ & $0.073 \pm 0.012$ & $0.254 \pm 0.131$ & $0.121 \pm 0.014$ \\
Triacylglycerol (mmol/L) & $1.34 \pm 0.10^{\mathrm{a}}$ & $0.649 \pm 0.116^{\mathrm{c}}$ & $0.497 \pm 0.093^{\mathrm{c}}$ & $1.20 \pm 0.17^{\mathrm{ab}}$ & $0.855 \pm 0.059^{\mathrm{bc}}$ \\
Phospholipids (mmol/L) & $0.233 \pm 0.008^{\mathrm{a}}$ & $0.198 \pm 0.011^{\mathrm{a}}$ & $0.162 \pm 0.006^{\mathrm{b}}$ & $0.217 \pm 0.009^{\mathrm{a}}$ & $0.207 \pm 0.009^{\mathrm{a}}$ \\
Free fatty acids (mEq/L) & $2.48 \pm 0.35$ & $1.97 \pm 0.28$ & $1.60 \pm 0.22$ & $2.17 \pm 0.27$ & $1.80 \pm 0.26$ \\
\hline
\end{tabular}

${ }^{1} \mathrm{RY}$, raw yam; BY, boiled yam.

${ }^{2}$ Mean values within a row with unlike superscript letters were significantly different $(p<0.05)$. Data were analyzed with one-way ANOVA with Tukey's post-test.

${ }^{3} 15 \mathrm{RY}$ and $30 \mathrm{RY}$, rats fed $15 \%$ and $30 \%$ raw yam diets, respectively.

${ }^{4} 15 \mathrm{BY}$ and $30 \mathrm{BY}$, rats fed $15 \%$ and $30 \%$ boiled yam diets, respectively.

Table 4. Weight of liver, kidney and epididymal fat pad, and liver cholesterol in rats fed diets supplemented with raw or boiled yam. ${ }^{1,2}$

\begin{tabular}{lccccc}
\hline & Control & $15 \mathrm{RY}^{3}$ & $30 \mathrm{RY}^{3}$ & $15 \mathrm{BY}^{4}$ & $30 \mathrm{BY}^{4}$ \\
\hline Tissue weight & & & & & \\
$\quad$ Liver $(\mathrm{g} / 100 \mathrm{~g} \mathrm{BW})$ & $4.21 \pm 0.14$ & $3.98 \pm 0.14$ & $3.93 \pm 0.16$ & $3.92 \pm 0.06$ & $4.07 \pm 0.11$ \\
$\quad$ Epididymal fat pad $(\mathrm{g} / 100 \mathrm{~g} \mathrm{BW})$ & $1.50 \pm 0.13^{\mathrm{ab}}$ & $1.26 \pm 0.08^{\mathrm{bc}}$ & $1.09 \pm 0.04^{\mathrm{c}}$ & $1.63 \pm 0.05^{\mathrm{ab}}$ & $1.66 \pm 0.10^{\mathrm{a}}$ \\
$\quad$ Testis $(\mathrm{g} / 100 \mathrm{~g}$ body BW) & $0.901 \pm 0.014$ & $0.955 \pm 0.022$ & $0.961 \pm 0.034$ & $0.924 \pm 0.031$ & $0.892 \pm 0.025$ \\
Liver cholesterol $(\mu \mathrm{mol} / \mathrm{g}$ liver $)$ & $6.77 \pm 0.39^{\mathrm{b}}$ & $9.57 \pm 0.87^{\mathrm{ab}}$ & $11.0 \pm 1.5^{\mathrm{a}}$ & $7.39 \pm 0.88^{\mathrm{ab}}$ & $6.84 \pm 0.52^{\mathrm{b}}$ \\
Liver triacylglycerol $(\mu \mathrm{mol} / \mathrm{g}$ liver $)$ & $42.9 \pm 3.0$ & $37.8 \pm 4.9$ & $35.5 \pm 9.3$ & $36.6 \pm 4.6$ & $33.8 \pm 6.1$ \\
\hline
\end{tabular}

${ }^{1}$ RY, raw yam; BY, boiled yam; BW, body weight.

${ }^{2}$ Mean values within a row with unlike superscript letters were significantly different $(p<0.05)$. Data were analyzed with one-way ANOVA with Tukey's post-test.

${ }^{3} 15 \mathrm{RY}$ and $30 \mathrm{RY}$, rats fed $15 \%$ and $30 \%$ raw yam diets, respectively.

${ }^{4} 15 \mathrm{BY}$ and $30 \mathrm{BY}$, rats fed $15 \%$ and $30 \%$ boiled yam diets, respectively.

Table 5. Fecal weight and bile acid excretion in rats fed diets supplemented with raw or boiled yam. ${ }^{1,2}$

\begin{tabular}{|c|c|c|c|c|c|}
\hline & Control & $15 \mathrm{RY}^{3}$ & $30 R Y^{3}$ & $15 \mathrm{BY}^{4}$ & $30 B Y^{4}$ \\
\hline Dry fecal weight (g/3 d) & $5.06 \pm 0.27^{\mathrm{a}}$ & $6.09 \pm 0.37^{\mathrm{a}}$ & $8.81 \pm 0.63^{b}$ & $5.12 \pm 0.18^{\mathrm{a}}$ & $6.09 \pm 0.40^{\mathrm{a}}$ \\
\hline \multicolumn{6}{|l|}{ Total bile acids } \\
\hline Excretion $(\mu \mathrm{mol} / 3 \mathrm{~d})$ & $30.5 \pm 5.6^{\mathrm{a}}$ & $33.8 \pm 4.0^{\mathrm{ab}}$ & $34.4 \pm 5.0^{\mathrm{ab}}$ & $56.7 \pm 5.7^{\mathrm{c}}$ & $51.1 \pm 3.8^{\mathrm{bc}}$ \\
\hline Concentration $(\mu \mathrm{mol} / \mathrm{g})$ & $6.22 \pm 1.23^{\mathrm{ab}}$ & $5.75 \pm 0.88^{\mathrm{ab}}$ & $3.95 \pm 0.57^{\mathrm{a}}$ & $11.0 \pm 0.9^{c}$ & $8.64 \pm 0.91^{b c}$ \\
\hline \multicolumn{6}{|l|}{ Neutral sterol } \\
\hline Cholesterol $(\mu \mathrm{mol} / 3 \mathrm{~d})$ & $17.3 \pm 2.0^{\mathrm{b}}$ & $16.7 \pm 1.6^{\mathrm{b}}$ & $31.9 \pm 3.1^{\mathrm{a}}$ & $19.0 \pm 1.1^{\mathrm{b}}$ & $18.4 \pm 18.4^{\mathrm{b}}$ \\
\hline Coprostanol $(\mu \mathrm{mol} / 3 \mathrm{~d})$ & $8.79 \pm 0.77^{\mathrm{a}}$ & $4.78 \pm 0.78^{\mathrm{b}}$ & $1.21 \pm 0.77^{\mathrm{c}}$ & $7.20 \pm 0.57^{\mathrm{ab}}$ & $8.34 \pm 0.41^{\mathrm{a}}$ \\
\hline
\end{tabular}

\footnotetext{
${ }^{1}$ RY, raw yam; BY, boiled yam. one-way ANOVA with Tukey's post-test.

${ }^{3} 15 \mathrm{RY}$ and $30 \mathrm{RY}$, rats fed $15 \%$ and $30 \%$ raw yam diets, respectively.

${ }^{4} 15 \mathrm{BY}$ and $30 \mathrm{BY}$, rats fed $15 \%$ and $30 \%$ boiled yam diets, respectively.
}

${ }^{2}$ Mean values within a row with unlike superscript letters were significantly different $(p<0.05)$. Data were analyzed with

Table 6 shows the mRNA content of hepatic CYP7A1, HMG-CoA-r, LDL-R, apo B and MTP in rats fed RY and BY. The mRNA content of MTP in rats fed the $30 \%$ RY diet decreased to $70 \%$ of the control group. The administration of $15 \%$ BY diet significantly increased the mRNA content of hepatic CYP7A1 and the administration of $30 \% \mathrm{BY}$ diet tended to increase hepatic CYP7A1 mRNA compared with those fed the control diet. Other hepatic mRNA contents did not differ between any of the groups.

Table 7 indicates $\mathrm{pH}$ and weight of the cecal contents and wall in rats fed RY and BY. There were significant increases in the cecal content caused by an intake of increasing doses of RY, whereas such increases were not 
Table 6. Hepatic mRNA level in rats fed diets supplemented with raw or boiled yam. ${ }^{1,2}$

\begin{tabular}{|c|c|c|c|c|c|}
\hline Gene & Control & $15 R Y^{3}$ & $30 R Y^{3}$ & $15 \mathrm{BY}^{4}$ & $30 \mathrm{BY}^{4}$ \\
\hline \multicolumn{6}{|c|}{ (Arbitrary units) } \\
\hline CYP7A1 & $100 \pm 14^{b}$ & $119 \pm 27^{\mathrm{ab}}$ & $178 \pm 24^{\mathrm{ab}}$ & $229 \pm 41^{\mathrm{a}}$ & $220 \pm 33^{\mathrm{ab}}$ \\
\hline HMG-CoA-r & $100 \pm 11$ & $96.6 \pm 8.4$ & $110 \pm 12$ & $145 \pm 21$ & $145 \pm 20$ \\
\hline LDL-R & $100 \pm 7$ & $96.3 \pm 8.2$ & $88.8 \pm 9.5$ & $101 \pm 5$ & $103 \pm 12$ \\
\hline Apo B & $100 \pm 4$ & $96.1 \pm 5.5$ & $98.8 \pm 13.6$ & $99.7 \pm 3.4$ & $111 \pm 5$ \\
\hline MTP & $100 \pm 4^{\mathrm{ab}}$ & $75.0 \pm 7.3^{\mathrm{bc}}$ & $68.8 \pm 8.6^{c}$ & $103 \pm 6^{a}$ & $109 \pm 7^{\mathrm{a}}$ \\
\hline
\end{tabular}

${ }^{1}$ RY, raw yam; BY, boiled yam; CYP7A1, cholesterol $7 \alpha$-hydroxylase; HMG-CoA-r, hydroxymethylglutaryl-CoA reductase; LDL-R, LDL receptor; Apo B, apolipoprotein B; MTP, microsomal TAG transfer protein.

${ }^{2}$ Mean values within a row with unlike superscript letters were significantly different $(p<0.05)$. Data were analyzed with one-way ANOVA with Tukey's post-test.

${ }^{3} 15 \mathrm{RY}$ and $30 \mathrm{RY}$, rats fed $15 \%$ and $30 \%$ raw yam diets, respectively.

${ }^{4} 15 \mathrm{BY}$ and $30 \mathrm{BY}$, rats fed $15 \%$ and $30 \%$ boiled yam diets, respectively.

Table 7. Weight and $\mathrm{pH}$ of cecal content and cecal wall in rats fed diets supplemented with raw or boiled yam. ${ }^{1,2}$

\begin{tabular}{|c|c|c|c|c|c|}
\hline & Control & $15 \mathrm{RY}^{3}$ & $30 R Y^{3}$ & $15 \mathrm{BY}^{4}$ & $30 \mathrm{BY}^{4}$ \\
\hline \multicolumn{6}{|l|}{ Cecal content } \\
\hline $\mathrm{pH}$ & $7.14 \pm 0.11^{\mathrm{b}}$ & $6.64 \pm 0.17^{\mathrm{ab}}$ & $6.15 \pm 0.19^{\mathrm{a}}$ & $6.87 \pm 0.08^{b}$ & $6.79 \pm 0.07^{b}$ \\
\hline Weight (g) & $3.12 \pm 0.27^{\mathrm{a}}$ & $6.14 \pm 0.49^{b}$ & $11.1 \pm 0.63^{\mathrm{c}}$ & $3.38 \pm 0.25^{\mathrm{a}}$ & $4.08 \pm 0.28^{\mathrm{a}}$ \\
\hline Cecal wall (g) & $0.812 \pm 0.052^{\mathrm{a}}$ & $1.13 \pm 0.12^{\mathrm{a}}$ & $1.79 \pm 0.14^{\mathrm{b}}$ & $0.874 \pm 0.028^{\mathrm{a}}$ & $1.10 \pm 0.06^{\mathrm{a}}$ \\
\hline
\end{tabular}

${ }^{1}$ RY, raw yam; BY, boiled yam.

${ }^{2}$ Mean values within a row with unlike superscript letters were significantly different $(p<0.05)$. Data were analyzed with one-way ANOVA with Tukey's post-test.

${ }^{3} 15 \mathrm{RY}$ and $30 \mathrm{RY}$, rats fed $15 \%$ and $30 \%$ raw yam diets, respectively.

${ }^{4} 15 \mathrm{BY}$ and $30 \mathrm{BY}$, rats fed $15 \%$ and $30 \%$ boiled yam diets, respectively.

Table 8. Effect of raw and boiled yam on cecal pools and concentrations of SCFAs and succinate., ${ }^{1,2}$

\begin{tabular}{|c|c|c|c|c|c|}
\hline & Control & $15 \mathrm{RY}^{3}$ & $30 R Y^{3}$ & $15 \mathrm{BY}^{4}$ & $30 \mathrm{BY}^{4}$ \\
\hline \multicolumn{6}{|l|}{ Pool } \\
\hline Acetate $(\mu \mathrm{mol} /$ caecum $)$ & $128 \pm 14^{\mathrm{a}}$ & $272 \pm 33^{b}$ & $457 \pm 52^{c}$ & $134 \pm 15^{\mathrm{a}}$ & $181 \pm 18^{\mathrm{ab}}$ \\
\hline Propionate ( $\mu \mathrm{mol} /$ caecum$)$ & $42.0 \pm 3.9^{\mathrm{a}}$ & $118 \pm 18^{b}$ & $242 \pm 28^{c}$ & $55.7 \pm 6.1^{\mathrm{ab}}$ & $68.4 \pm 11.4^{\mathrm{ab}}$ \\
\hline$n$-Butyrate ( $\mu \mathrm{mol} /$ caecum) & $29.8 \pm 2.4^{\mathrm{a}}$ & $152 \pm 17^{c}$ & $265 \pm 22^{\mathrm{d}}$ & $62.3 \pm 6.6^{\mathrm{ab}}$ & $88.9 \pm 4.5^{\mathrm{b}}$ \\
\hline $\operatorname{Total}^{5}(\mu \mathrm{mol} /$ caecum $)$ & $200 \pm 19^{a}$ & $543 \pm 53^{\mathrm{b}}$ & $964 \pm 92^{c}$ & $252 \pm 25^{\mathrm{a}}$ & $339 \pm 29^{\mathrm{ab}}$ \\
\hline Succinate $(\mu \mathrm{mol} / \mathrm{caecum})$ & $4.76 \pm 1.35^{\mathrm{a}}$ & $96.3 \pm 65.2^{\mathrm{a}}$ & $254 \pm 39^{b}$ & $7.45 \pm 2.11^{\mathrm{a}}$ & $46.1 \pm 17.0^{\mathrm{a}}$ \\
\hline \multicolumn{6}{|l|}{ Concentration } \\
\hline Acetate $(\mu \mathrm{mol} / \mathrm{g})$ & $41.1 \pm 3.8$ & $44.0 \pm 3.8$ & $41.1 \pm 3.7$ & $39.2 \pm 2.5$ & $44.0 \pm 1.5$ \\
\hline Propionate $(\mu \mathrm{mol} / \mathrm{g})$ & $13.5 \pm 0.8^{\mathrm{a}}$ & $18.9 \pm 1.7^{\mathrm{ab}}$ & $21.6 \pm 1.8^{\mathrm{b}}$ & $16.2 \pm 0.9^{\mathrm{ab}}$ & $16.3 \pm 2.1^{\mathrm{ab}}$ \\
\hline$n$-Butyrate $(\mu \mathrm{mol} / \mathrm{g})$ & $9.87 \pm 1.15^{\mathrm{a}}$ & $24.9 \pm 1.9^{c}$ & $23.9 \pm 1.3^{\mathrm{bc}}$ & $18.5 \pm 1.5^{\mathrm{b}}$ & $22.1 \pm 1.4^{b c}$ \\
\hline $\operatorname{Total}^{5}(\mu \mathrm{mol} / \mathrm{g})$ & $64.5 \pm 5.3^{\mathrm{a}}$ & $87.8 \pm 3.5^{\mathrm{b}}$ & $86.6 \pm 5.4^{\mathrm{b}}$ & $73.9 \pm 3.1^{\mathrm{ab}}$ & $82.5 \pm 2.1^{\mathrm{b}}$ \\
\hline Succinate $(\mu \mathrm{mol} / \mathrm{g})$ & $1.49 \pm 0.38^{\mathrm{a}}$ & $14.8 \pm 9.9^{\mathrm{ab}}$ & $22.6 \pm 2.8^{\mathrm{b}}$ & $2.28 \pm 0.71^{\mathrm{ab}}$ & $10.9 \pm 4.0^{\mathrm{ab}}$ \\
\hline Molar ratio (Ace/Pro/But) & $64 / 21 / 15$ & $50 / 21 / 29$ & $47 / 25 / 28$ & $53 / 22 / 25$ & $53 / 20 / 27$ \\
\hline
\end{tabular}

${ }^{1}$ RY, raw yam; BY, boiled yam; Ace, acetate; Pro, propionate; But, butyrate.

${ }^{2}$ Mean values within a row with unlike superscript letters were significantly different $(p<0.05)$. Data were analyzed with one-way ANOVA with Tukey's post-test.

${ }^{3} 15 \mathrm{RY}$ and $30 \mathrm{RY}$, rats fed $15 \%$ and $30 \%$ raw yam diets, respectively.

${ }^{4} 15 \mathrm{BY}$ and $30 \mathrm{BY}$, rats fed $15 \%$ and $30 \%$ boiled yam diets, respectively.

${ }^{5}$ acetate + propionate $+n$-butyrate.

observed in rats fed BY. Pools of acetate, propionate and n-butyrate were significantly higher in rats fed RY compared with those fed the control diet, whereas these increases were not observed in rats fed BY (Table 8).
Pools of acetate, propionate and $n$-butyrate in rats fed the $30 \%$ RY diet were $257 \%, 476 \%$ and $789 \%$ greater $(p<0.05)$ compared with those fed the control diet (Table 8). 


\section{DISCUSSION}

Yam contains a large amount of starch, including amylose, which comprises about $30 \%$ of the whole yam and is not easily digested without cooking (18). The RS content $(33.9 \%)$ in raw yams used in the present study was similar to the amylose content in yams from a study reported by Huang (18). Amylose gelatinized at a high temperature is easily digested. The content of RS was five times greater in RY compared with BY. The data indicates the amylose component of RS in Chinese yam becomes digestible when heated, even if heat treatment is brief. Many investigators have reported on the physiological effects of RS2; however, the sources of RS2 have been limited to raw starch from maize (19, 20 ), banana (21) and potato (22). Only a few studies have examined the effects of RS2 from RY on cecal fermentation; a large amount of RS2 is supplied to the large intestine by consumption of RY, and is then used as a substrate for intestinal bacteria. RS enhances fermentation in the large intestine and contributes to an increased production of SCFAs, especially butyrate $(8$, $23,24)$ and propionate $(25)$. In the present study, the effects of both cooked and uncooked yams on cecal fermentation were compared in rats, and found to be different. Strong positive correlations between RS intake and the content of cecal SCFAs were observed (acetate, $r=0.9006, \quad p<0.0001$; propionate, $r=0.9148, \quad p<$ 0.0001; butyrate, $r=0.9452, p<0.0001)$. Rats fed RY diets had a higher proportion of cecal butyrate compared to rats fed BY diets. These different effects of raw and boiled yams seem to be due to amounts of RS. RS has a hypertrophic effect on the large intestine, because butyrate is the predominant energy source for colonocytes $(26,27)$. We also observed enlarged ceca in rats fed diets supplemented with RY. At the same time, greater cecal SCFA concentrations, especially of butyrate, were caused by RY feeding. Butyrate generated by fermentation seems to promote cell proliferation in the cecum. From these results, RY is suggested to be an effective source of RS for intestinal fermentation, resulting in an increased production of butyrate.

SCFAs suppress hepatic cholesterol and fatty acid synthesis, resulting in the reduction of plasma cholesterol concentration in rats (10). Many investigators also report that RS decreases serum cholesterol and TAG concentrations, and increases pools of cecal SCFA in rats $(4,5,19)$ and humans $(6)$. In the present study, RY, but not BY, reduced total and non-HDL cholesterol and TAG concentrations in plasma, while pools of cecal SCFAs in rats fed the RY diet were greater compared with the control and BY diets (Fig. 1 and Table 8). Negative correlations between cecal propionate and nonHDL cholesterol in plasma were found $(p=0.0166)$. However, RY feeding did not suppress the hepatic mRNA content of HMG-CoA-r. Younes et al. reported that the activity of hepatic HMG-CoA-r was increased twofold by RS (28). Therefore, RY may induce a plasma cholesterol-lowering effect independent of the inhibition of hepatic cholesterol synthesis by SCFAs. Further investigation is required to evaluate the direct effect of fermentation of RY in the large intestine on lipid metabolism.

High liver cholesterol concentrations were observed in rats fed the RY diet compared with rats fed the control and BY diets. The liver plays an important role in the release and uptake of cholesterol as well as its synthesis and degradation. In the present study, the mRNA content of hepatic MTP, which transfers lipids onto the newly synthesized apo B polypeptide and is involved in VLDL assembly and release (29), was inhibited by RY feeding. Plasma non-HDL cholesterol concentration was significantly lower in rats fed RY and correlated with hepatic MTP mRNA content in rats fed the control and RY diets $(r=0.588, p=0.010, n=18)$. Hepatic LDL$\mathrm{R}$ mRNA content was not affected by RY feeding. Therefore, a reduced plasma non-HDL-cholesterol concentration and an increased liver cholesterol concentration may be due to suppressed release of VLDL from the liver. In the present study, it remains unclear how the effect of RS is triggered. Marcil et al. reported that butyrate inhibits MTP expression in Caco- 2 cells, but not hepatocytes (30). The presence of some SCFAs may also be related to the suppression of MTP expression and VLDL release in the liver.

In many previous studies, enhanced cholesterol catabolism has been reported to contribute to the reduction of plasma and liver cholesterol concentrations (31-33). In the current study, however, plasma and liver cholesterol concentrations did not correlate with the hepatic mRNA content of CYP7A1, which is a rate-limiting enzyme in bile acid synthesis $(p=0.9088$ and $p=0.5574$, respectively). The intake of BY, but not RY, increased fecal bile acid excretion, although RS in raw potato starch was effective in excreting bile acid into feces (28). This discrepancy may be due to the low ability of RS in yam and high ability of dietary fiber in BY to excrete bile acid. However, cholesterol excretion increased in rats fed the 30\% RY diet. Levrat et al. reported that RS feeding also caused an increased excretion of cholesterol in feces (34). Therefore, increased excretion of cholesterol, but not bile acid, by RS at least partially contributes to the lowering of nonHDL cholesterol by RY feeding, through the inhibition of cholesterol absorption. In addition, it has been reported that RS reduces energy absorption leading to less abdominal fat deposit and lower serum TAG concentration (35). Reduced energy absorption may be involved in lowering plasma TAG levels and weight of epididymal fat pads by RY feeding.

In conclusion, raw yam is effective as a source of RS and facilitates the production of SCFAs, especially butyrate and propionate in rat cecum. In addition, raw yam may have a plasma-cholesterol lowering effect due to the inhibition of VLDL release. However, these results require further investigation to explain the relationship between cholesterol concentrations in plasma and liver and other factors (including fermentation products) accompanying cholesterol metabolism. 


\section{Acknowledgments}

This study was supported by the City Area Program in Industry-Academia-Government Joint Research (Tokachi area) from the Ministry of Education, Culture, Sports, Science and Technology, Japan. We are grateful to Martin Meadows, M. Ed, for checking the English.

\section{REFERENCES}

1) Weng W, Chen J. 1996. The eastern perspective on functional foods based on traditional Chinese medicine. Nutr Rev 54: S11-S16.

2) Jeon JR, Lee JS, Lee CH, Kim JY, Kim SD, Nam DH. 2006. Effect of ethanol extract of dried Chinese yam (Dioscorea batatas) flour containing dioscin on gastrointestinal function in rat model. Arch Pharm Res 29: 348-353.

3) Lee SC, Tsai CC, Chen JC, Lin JG, Lin CC, Hu ML, Lu S. 2002. Effects of "Chinese yam" on hepato-nephrotoxicity of acetaminophen in rats. Acta Pharmacol Sin 23: 503-508.

4) de Deckere EA, Kloots WJ, van Amelsvoort JM. 1993. Resistant starch decreases serum total cholesterol and triacylglycerol concentrations in rats. J Nutr 123: 2142-2151.

5) Han KH, Fukushima M, Shimizu K, Kojima M, Ohba K, Tanaka A, Shimada K, Sekikawa M, Nakano M. 2003. Resistant starches of beans reduce the serum cholesterol concentration in rats. J Nutr Sci Vitaminol 49: 281-286.

6) Behall KM, Scholfield DJ, Yuhaniak I, Canary J. 1989. Diets containing high amylose vs amylopectin starch: effects on metabolic variables in human subjects. $\mathrm{Am} \mathrm{J}$ Clin Nutr 49: 337-344.

7) Le Leu RK, Brown IL, Hu Y, Morita T, Esterman A, Young GP. 2007. Effect of dietary resistant starch and protein on colonic fermentation and intestinal tumourigenesis in rats. Carcinogenesis 28: 240-245.

8) Morita T, Kasaoka S, Hase K, Kiriyama S. 1999. Psyllium shifts the fermentation site of high-amylose cornstarch toward the distal colon and increases fecal butyrate concentration in rats. J Nutr 129: 20812087.

9) Bird AR, Vuaran MS, King RA, Noakes M, Keogh J, Morell MK, Topping DL. 2008. Wholegrain foods made from a novel high-amylose barley variety (Himalaya 292) improve indices of bowel health in human subjects. Br J Nutr 99: 1032-1040.

10) Hara H, Haga S, Aoyama Y, Kiriyama S. 1999. Shortchain fatty acids suppress cholesterol synthesis in rat liver and intestine. J Nutr 129: 942-948.

11) Domokos M, Jakus J, Szeker K, Csizinszky R, Csiko G, Neogrady Z, Csordas A, Galfi P. 2010. Butyrate-induced cell death and differentiation are associated with distinct patterns of ROS in HT29-derived human colon cancer cells. Dig Dis Sci 55: 920-930.

12) Reeves PG, Nielsen FH, Fahey GC Jr. 1993. AIN-93 purified diets for laboratory rodents: final report of the American Institute of Nutrition ad hoc writing committee on the reformulation of the AIN-76A rodent diet. J Nutr 123: 1939-1951.

13) Folch J, Lees M, Sloane Stanley GH. 1957. A simple method for the isolation and purification of total lipides from animal tissues. J Biol Chem 226: 497-509.

14) Fletcher MJ. 1968. A colorimetric method for estimating serum triglycerides. Clin Chim Acta 22: 393-397.
15) Moundras C, Behr SR, Remesy C, Demigne C. 1997. Fecal losses of sterols and bile acids induced by feeding rats guar gum are due to greater pool size and liver bile acid secretion. J Nutr 127: 1068-1076.

16) Sheltawy MJ, Losowsky MS. 1975. Determination of faecal bile acids by an enzymic method. Clin Chim Acta 64: 127-132.

17) Hoshi S, Sakata T, Mikuni K, Hashimoto H, Kimura S. 1994. Galactosylsucrose and xylosylfructoside alter digestive tract size and concentrations of cecal organic acids in rats fed diets containing cholesterol and cholic acid. J Nutr 124: 52-60.

18) Huang CC. 2009. Physicochemical, pasting and thermal properties of tuber starches as modified by guar gum and locust bean gum. Int J Food Sci Technol 44: 5057.

19) Liu X, Ogawa H, Kishida T, Ebihara K. 2009. Hypolipidaemic effect of maize starch with different amylose content in ovariectomized rats depends on intake amount of resistant starch. Br J Nutr 101: 328-339.

20) Topping DL, Gooden JM, Brown IL, Biebrick DA, McGrath L, Trimble RP, Choct M, Illman RJ. 1997. A high amylose (amylomaize) starch raises proximal large bowel starch and increases colon length in pigs. J Nutr 127: $615-622$.

21) Langkilde AM, Champ M, Andersson H. 2002. Effects of high-resistant-starch banana flour (RS(2)) on in vitro fermentation and the small-bowel excretion of energy, nutrients, and sterols: an ileostomy study. Am J Clin Nutr 75: 104-111.

22) Martinez-Puig D, Perez JF, Castillo M, Andaluz A, Anguita M, Morales J, Gasa J. 2003. Consumption of raw potato starch increases colon length and fecal excretion of purine bases in growing pigs. J Nutr 133: 134-139.

23) Rideout TC, Liu Q, Wood P, Fan MZ. 2008. Nutrient utilisation and intestinal fermentation are differentially affected by the consumption of resistant starch varieties and conventional fibres in pigs. Br J Nutr 99: 984-992.

24) Toden S, Bird AR, Topping DL, Conlon MA. 2007. Differential effects of dietary whey, casein and soya on colonic DNA damage and large bowel SCFA in rats fed diets low and high in resistant starch. Br J Nutr 97: 535-543.

25) Han KH, Sekikawa M, Shimada K, Sasaki K, Ohba K, Fukushima M. 2004. Resistant starch fraction prepared from kintoki bean affects gene expression of genes associated with cholesterol metabolism in rats. Exp Biol Med (Maywood) 229: 787-792.

26) Roediger WE. 1980. Role of anaerobic bacteria in the metabolic welfare of the colonic mucosa in man. Gut 21: 793-798.

27) Kien CL, Blauwiekel R, Bunn JY, Jetton TL, Frankel WL, Holst JJ. 2007. Cecal infusion of butyrate increases intestinal cell proliferation in piglets. J Nutr 137: 916922.

28) Younes H, Levrat MA, Demigne C, Remesy C. 1995. Resistant starch is more effective than cholestyramine as a lipid-lowering agent in the rat. Lipids 30: 847-853.

29) Gregg RE, Wetterau JR. 1994. The molecular basis of abetalipoproteinemia. Curr Opin Lipidol 5: 81-86.

30) Marcil V, Delvin E, Garofalo C, Levy E. 2003. Butyrate impairs lipid transport by inhibiting microsomal triglyceride transfer protein in Caco-2 cells. J Nutr 133: 21802183. 
31) Bartley GE, Yokoyama W, Young SA, Anderson WH, Hung SC, Albers DR, Langhorst ML, Kim H. 2010. Hypocholesterolemic effects of hydroxypropyl methylcellulose are mediated by altered gene expression in hepatic bile and cholesterol pathways of male hamsters. J Nutr 140: 1255-1260.

32) Jiao R, Zhang Z, Yu H, Huang Y, Chen ZY. 2010. Hypocholesterolemic activity of grape seed proanthocyanidin is mediated by enhancement of bile acid excretion and up-regulation of CYP7A1. J Nutr Biochem 21: 11341139.

33) Kim WK, Chung MK, Kang NE, Kim MH, Park OJ. 2003. Effect of resistant starch from corn or rice on glucose control, colonic events, and blood lipid concentrations in streptozotocin-induced diabetic rats. J Nutr Biochem 14: $166-172$.

34) Levrat MA, Moundras C, Younes H, Morand C, Demigne C, Remesy C. 1996. Effectiveness of resistant starch, compared to guar gum, in depressing plasma cholesterol and enhancing fecal steroid excretion. Lipids 31: 1069-1075.

35) de Deckere EA, Kloots WJ, van Amelsvoort JM. 1995. Both raw and retrograded starch decrease serum triacylglycerol concentration and fat accretion in the rat. Br J Nutr 73: 287-298. 